\title{
Signaling pathways regulating FSH- and amphiregulin-induced meiotic resumption and cumulus cell expansion in the pig
}

\author{
R Prochazka, M Blaha and L Nemcova \\ Laboratory of Developmental Biology, Institute of Animal Physiology and Genetics, Academy of Sciences of the Czech \\ Republic, Rumburska 89, 27721 Libechov, Czech Republic \\ Correspondence should be addressed to R Prochazka; Email: prochazka@iapg.cas.cz
}

\begin{abstract}
To define signaling pathways that drive FSH- and epidermal growth factor (EGF)-like peptide-induced cumulus expansion and oocyte meiotic resumption, in vitro cultured pig cumulus-oocyte complexes were treated with specific protein kinase inhibitors. We found that FSH-induced maturation of oocytes was blocked in germinal vesicle (GV) stage by protein kinase A (PKA), MAPK14, MAPK3/1, and EGF receptor (EGFR) tyrosine kinase inhibitors (H89, SB203580, U0126, and AG1478 respectively) whereas phosphoinositide-3-kinase/v-akt murine thymoma viral oncogene homolog (PI3K/AKT) inhibitor (LY294002) blocked maturation of oocytes in metaphase I (MI). Amphiregulin (AREG)-induced maturation of oocytes was efficiently blocked in GV by U0126, AG1478, and low concentrations of LY294002; H89, SB203580, and high concentrations of LY294002 allowed the oocytes to undergo breakdown of GV and blocked maturation in MI. Both FSH- and AREG-induced cumulus expansion was incompletely inhibited by $\mathbf{H 8 9}$ and completely inhibited by SB203580, U0126, AG1478, and LY294002. The inhibitors partially or completely inhibited expression of expansion-related genes (HAS2, PTGS2, and TNFAIP6) with two exceptions: H89 inhibited only TNFAIP6 expression and LY294002 increased expression of PTGS2. The results of this study are consistent with the idea that PKA and MAPK14 pathways are essential for FSH-induced transactivation of the EGFR, and synthesis of EGF-like peptides in cumulus cells and MAPK3/1 is involved in regulation of transcriptional and posttranscriptional events in cumulus cells required for meiotic resumption and cumulus expansion. PI3K/AKT signaling is important for regulation of cumulus expansion, AREG-induced meiotic resumption, and oocyte $\mathrm{MI} / \mathrm{MII}$ transition. The present data also indicate the existence of an FSH-activated and PKA-independent pathway involved in regulation of HAS2 and PTGS2 expression in cumulus cells. Reproduction (2012) $\mathbf{1 4 4} 535-546$
\end{abstract}

\section{Introduction}

The resumption of meiosis is initiated in ovarian follicles by the preovulatory peak of $\mathrm{LH}$. In the mouse and rat, $\mathrm{LH}$ binds to its receptors on mural granulosa cells and stimulates expression of epidermal growth factor (EGF)-like peptides (Park et al. 2004, Ashkenazi et al. 2005). These peptides (amphiregulin (AREG), epiregulin (EREG), and betacellulin (BTC)) are produced as membrane-bound pro-peptides that require a proteolytic step to be released into the follicular environment (Ashkenazi et al. 2005). They then act directly on mural granulosa as well as cumulus cells and stimulate resumption of meiosis and expansion of the cumulus. In addition, a regulatory loop between the mural granulosa and the cumulus cells exists in the preovulatory follicles, which ensures production of AREG and EREG also in the cumulus cell compartment (Shimada et al. 2006). The EGF-like peptides are also produced in cumulus cells of in vitro cultured cumulus-oocyte complexes (COCs) upon stimulation by FSH and trigger resumption of meiosis (Downs \& Chen 2008). The data published by our and other laboratories strongly suggest that similar mechanisms work also in large animal species (Prochazka et al. 2000, 2003, 2011, Akaki et al. 2009, Yamashita et al. 2009). We have recently shown that FSH induces expression of AREG and EREG but not BTC in cultured pig COCs and that these peptides stimulate expansion of cumulus cells, maturation of oocyte, and acquisition of the oocyte developmental competence. However, we have also pointed out lower efficiency of EGF-like peptides compared with $\mathrm{FSH}$, in inducing expression of expansion-related genes and their inability to stimulate protein kinase $A$ (PKA) and production of progesterone in cultured COCs (Prochazka et al. 2011). These results raise a question about specific roles of gonadotropin- and EGF-like factor-stimulated signaling pathways in cumulus cells and about their significance for resumption of meiosis and cumulus expansion.

$\mathrm{FSH} / \mathrm{LH}$ binding to their membrane receptors leads to a prompt activation of several signaling pathways. A well-characterized signaling cascade is the G-proteinmediated activation of adenylate cyclase and subsequent 
production of cAMP that in turn activates PKA. The PKA phosphorylates many substrates within the cell including transcription factors SP1/SP3 and CREB that control transcription of specific genes in cumulus and granulosa cells (Gonzalez-Robayna et al. 2000). However, recent studies have shown that FSH signaling in granulosa and also in cumulus cells is more complex and some molecular events occur even independently of PKA activation through cAMP-activated exchange factor pathway (Wayne et al. 2007). The gonadotropin-induced production of EGF-like peptides leads to a transactivation of EGF receptor (EGFR; Conti et al. 2006) as these peptides bind to a classical EGFR (ERBB1), activate its intrinsic tyrosine kinase, and downstream signaling cascades, including MAPK3/1, MAPK14, and phosphoinositide-3-kinase/v-akt murine thymoma viral oncogene homolog (PI3K/AKT) pathways (Shimada et al. 2006, Li et al. 2008, Hsieh et al. 2011). Therefore, gonadotropins activate a broad signaling network in cultured COCs, which results in essential changes in transcription profiling in the cumulus cells and consequently in series of posttranscriptional molecular events in the oocytes leading to the resumption of meiosis.

The aim of this work was to define specific roles of signaling pathways activated in cumulus cells by the FSH and EGF-like peptides in major events accompanying meiotic resumption in the pig. For this purpose, specific inhibitors of PKA, MAPK14, MAPK3/1, PI3K/AKT, and EGFR tyrosine kinase were employed and their effects on maturation of oocytes, expansion of cumulus cells, and expression of the expansion-related genes, namely hayluronan synthase 2 (HAS2), prostaglandin-endoperoxidase synthase 2 (PTGS2), and tumor necrosis factor $\alpha$-induced protein 6 (TNFAIP6), were studied.

\section{Results}

\section{PKA inhibition}

The FSH-induced activity of PKA was gradually inhibited in COCs by $5-20 \mu \mathrm{M} \mathrm{H} 89$. The activity of PKA at the highest concentration of $\mathrm{H} 89(20 \mu \mathrm{M})$ was indistinguishable from that found in control non-stimulated COCs (Fig. 1A, left panel). AREG did not stimulate activation of PKA in the COCs at all (Fig. 1A, right panel).

FSH and AREG equally stimulated maturation of the oocytes to metaphase II (MII; 78 vs $74 \%$ respectively). FSH-stimulated maturation of oocytes was almost completely blocked in germinal vesicle (GV) stage by $\mathrm{H} 89$ in concentrations of 5-15 $\mu \mathrm{M}$ (Fig. 1B); higher concentrations caused irreversible damage and degeneration of the oocytes during the period of culture. In contrast, AREG-induced resumption of meiosis was not blocked by any of the used concentrations of $\mathrm{H} 89$ and most oocytes underwent breakdown of the GV (GVBD) or proceeded to MII; the completion of meiosis to MII was, however, gradually decreased by increasing concentrations of $\mathrm{H} 89$ (Fig. 1B). The FSH- and AREGinduced expansion of cumulus cells was gradually but incompletely inhibited by $\mathrm{H} 89$ in concentrations of 5-20 $\mu \mathrm{M}$ (Fig. 1C). Approximately $30 \%$ of COCs treated with 15 and $20 \mu \mathrm{M}$ H89 still exhibited expansion of outer layers of the cumulus (expansion 2). Both FSH- and AREG-induced expression of HAS2 and PTGS2 was not inhibited by $\mathrm{H} 89$ but the expression of TNFAIP6 was significantly decreased by the drug (Fig. 1D).

\section{MAPK14 inhibition}

Both FSH- and AREG-induced activity of MAPK14 was reduced to a base level or completely abolished by SB203580 in concentrations higher than $10 \mu \mathrm{M}$ (Fig. 2A). The FSH- and AREG-induced maturation of oocytes was differently affected by the SB203580. The FSH-induced resumption of meiosis was efficiently blocked at GV by SB203580 in $80-100 \%$ of oocytes (Fig. 2B). In contrast, only $39.6-44.6 \%$ of the AREGstimulated oocytes remained in GV after treatment with different concentrations of SB203580, which was not significantly different from the control group. Thus, the majority of AREG-stimulated oocytes resumed meiosis and underwent GVBD despite of the presence of the MAPK14 inhibitor, but the maturation was then blocked and few oocytes completed meiosis to MII stage (Fig. 2B). The expansion of cumulus cells was gradually inhibited by $5-20 \mu \mathrm{M}$ SB203580 regardless of whether it was induced by FSH or AREG (Fig. 2C). The expression of expansion-related genes was partially (HAS2 and PTGS2) or completely (TNFAIP6) inhibited by the drug in FSH-stimulated COCs. In the AREG-stimulated COCs, the inhibition was complete for all the three genes (Fig. 2D).

\section{MAPK3/1 inhibition}

The FSH- and AREG-induced MAPK3/1 activity was abolished or attenuated to a base level by the use of U0126 over the range of assessed concentration (1-10 $\mu \mathrm{M}$; Fig. 3A). The U0126 had the same effect on both FSH- and AREG-induced maturation of oocytes. The resumption of meiosis was effectively blocked at GV stage by all concentrations of $\cup 0126(1-10 \mu \mathrm{M})$, and completion of meiosis to MII stage was significantly decreased in all groups (Fig. 3B). The degree of FSH- and AREG-induced cumulus expansion was gradually decreased with increasing concentrations of U0126; the AREG-stimulated COCs were significantly more inhibited than the FSH-stimulated ones (Fig. 3C). Corresponding with this observation, the U0126 partially inhibited the $\mathrm{FSH}$-induced expression of the expansionrelated genes, but the AREG-induced expression of the genes was completely inhibited (Fig. 3D). 
A

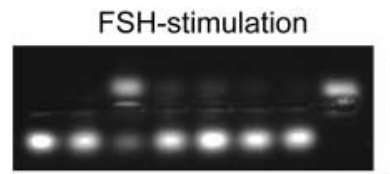

$N C F \frac{5101520}{F+H 89(\mu M)} P$

B

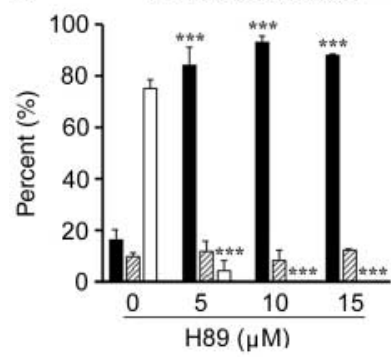

C

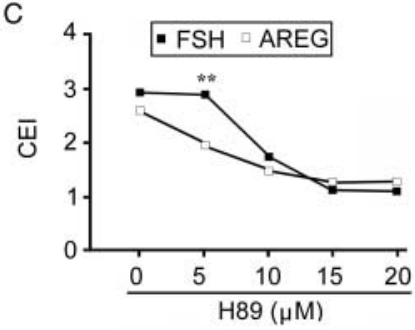

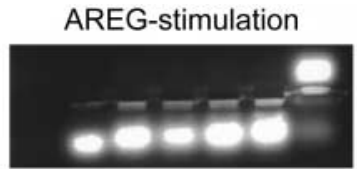

Phosphorylated

$\begin{array}{llll}N & \begin{array}{llll}1 & 2 & 4 & 6\end{array} \\ \text { Hour of culture } & P\end{array}$

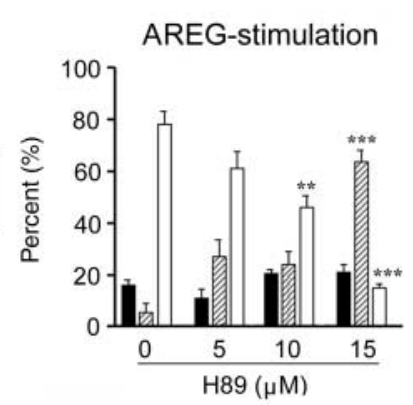

D
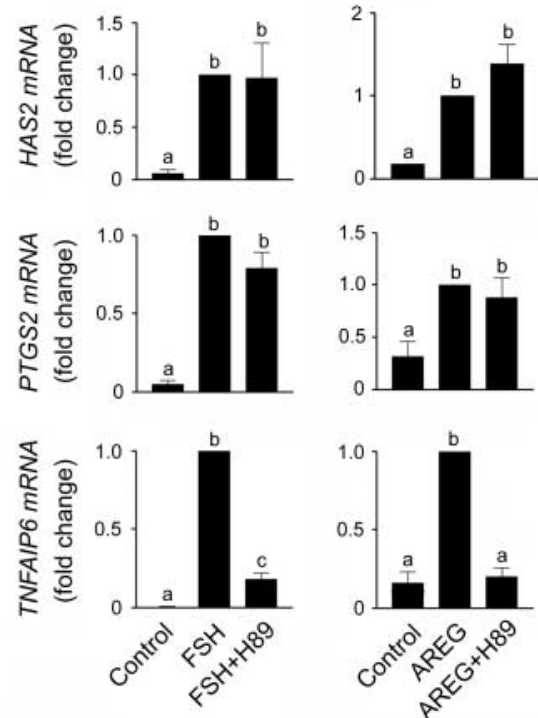

Figure 1 Effect of PKA inhibition on meiotic resumption and cumulus cell expansion. (A) Effect of H89 on FSH-induced activation of PKA in cultured COCs (left panel) and assessment of PKA activity in AREG-stimulated COCs (right panel). The panels display migration of the phosphorylated (+) and non-phosphorylated (-) PKA-specific substrate in an electric field following the PKA assay. Negative (N) and positive (P) control assays were run without the cells or with $25 \mathrm{ng}$ catalytic subunit of PKA respectively. C, control COCs cultured without stimulation; F, FSH. (B) Maturation of oocytes in medium with different concentrations of $\mathrm{H} 89$. Asterisks above the column indicate a significant difference from the corresponding control value found in oocytes cultured without $\mathrm{H} 89 ;{ }^{* *} P<0.01$, and ${ }^{* * *} P<0.001$. Approximately 90 COCs were included in each group. (C) Degree of cumulus expansion in COCs cultured in medium with different concentrations of $\mathrm{H} 89$. Double asterisk above the value means significant difference from the corresponding value within the same concentration of $\mathrm{H} 89 ;{ }^{* *} P<0.01$. (D) Effect of PKA inhibition on expression of expansion-related genes in cultured COCs. The relative abundance of specific gene mRNA was measured in COCs cultured in medium supplemented with $20 \mu \mathrm{M} \mathrm{H} 89$ for $4 \mathrm{~h}$ and is expressed in arbitrary units as fold strength increases in specific gene/HPRT1 ratio over the level found in COCs cultured with FSH or AREG. Different superscripts above the columns indicate significant differences $(P<0.05)$.

\section{EGFR tyrosine kinase inhibition}

The phosphorylation of EGFR was reduced to a base level by $0.5 \mu \mathrm{M}$ AG1478 and by all higher concentrations. Such a pattern of inhibition was identical for both FSH- and AREG-induced phosphorylation (Fig. 4A).

The AG1478 exhibited the same pattern of action on both FSH- and AREG-induced maturation of oocytes. Corresponding with the sensitivity test, the concentration from $0.5 \mu \mathrm{M}$ significantly inhibited resumption and completion of meiosis; 5 and $10 \mu \mathrm{M}$ AG1478 blocked $80-100 \%$ of the treated oocytes at GV stage (Fig. 4B). The degree of cumulus expansion was gradually decreased in both groups treated with $0.5 \mu \mathrm{M}$ AG1478 and higher concentrations of the drug. Nevertheless, the AREG-treated COCs displayed higher sensitivity to the EGFR tyrosine kinase inhibitor, as 5 and $10 \mu \mathrm{M}$ completely inhibited their expansion whereas the mean cumulus expansion index (CEI) of FSH-treated COCs was around 1.0 under the same conditions (Fig. 4C). AG1478 only partially decreased expression of HAS2 and TNFAIP6 in FSH-stimulated COCs whereas expression of PTGS2 was completely inhibited and so was expression of all the three genes in the AREG-stimulated COCs (Fig. 4D).

\section{PI3K/AKT inhibition}

The FSH-induced AKT activity was gradually decreased by $5-50 \mu \mathrm{M}$ LY29004. The concentration of $15 \mu \mathrm{M}$ appeared to reduce the AKT activity to a base line and higher concentrations further reduced the activity to an undetectable level. The AREG-induced AKT activity was already undetectable after using $20 \mu \mathrm{M}$ LY29004 (Fig. 5A).

The inhibitor did not block resumption of meiosis in the FSH-stimulated COCs; the great majority of oocytes underwent GVBD, but few of them reached MII stage 
A

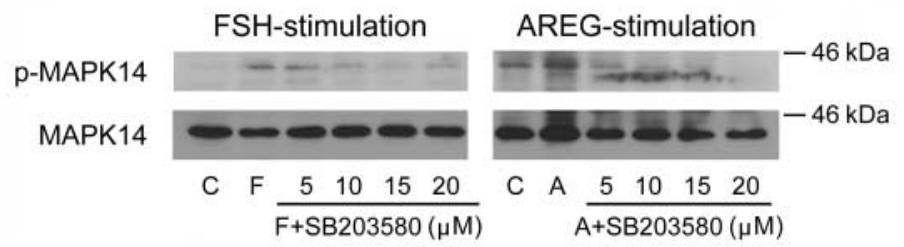

B $\quad$ FSH-stimulation

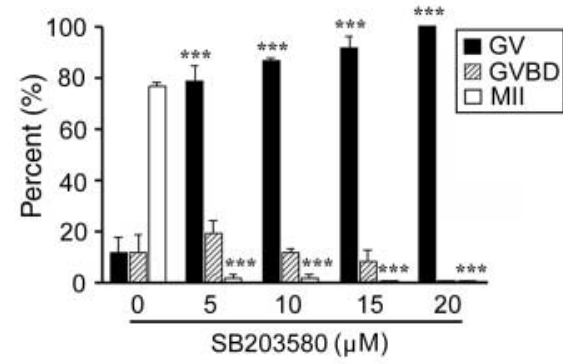

C

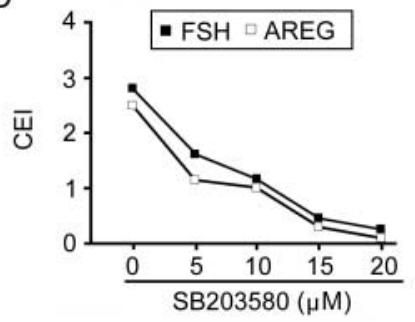

D
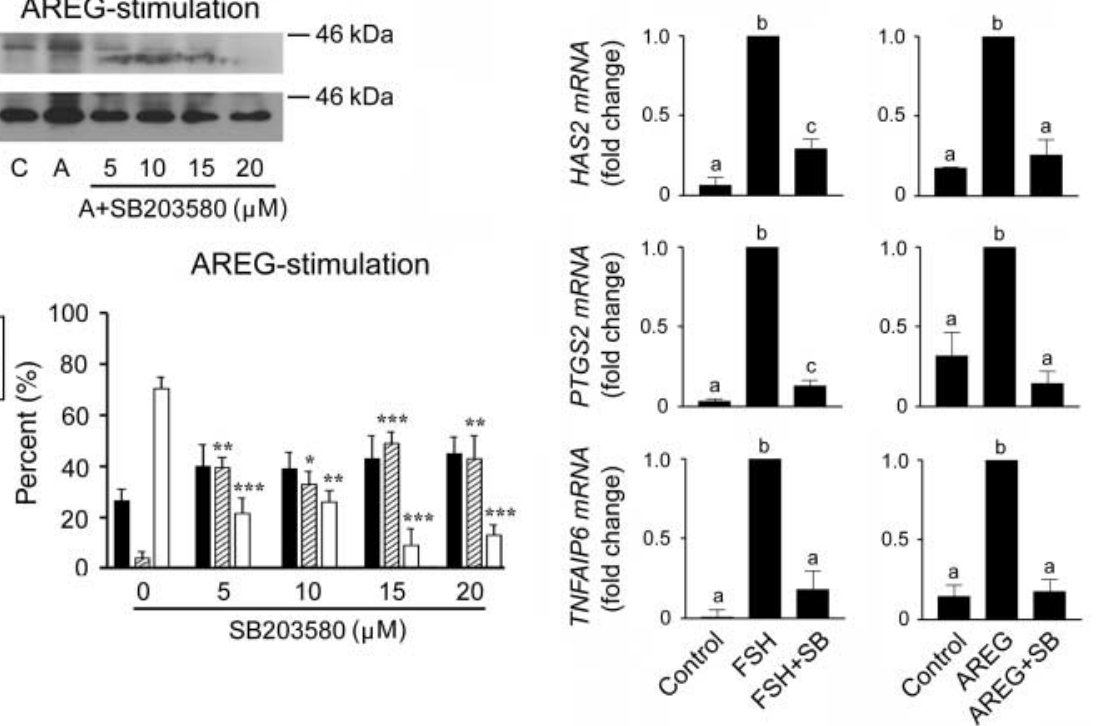

Figure 2 Effect of MAPK14 inhibition on meiotic resumption and cumulus cell expansion. (A) Effect of SB203580 on activation of MAPK14 in cultured COCs. The panels display immunoblotting of phosphorylated and total MAPK14 in FSH- and AREG-stimulated COCs cultured for $18 \mathrm{~h}$ in medium with different concentrations of SB203580. This experiment was repeated twice with similar results. C, control COCs cultured without stimulation; F, FSH; A, AREG. Position of molecular weight marker is on the right. (B) Maturation of oocytes in medium with different concentrations of SB203580. Asterisks above the column indicate a significant difference from the corresponding control value found in oocytes cultured without SB203580; ${ }^{*} P<0.05,{ }^{*} P<0.01$, and ${ }^{* * *} P<0.001$. Approximately 90 COCs were included in each group. (C) Degree of cumulus expansion in COCs cultured in medium with different concentrations of SB203580. (D) Effect of MAPK14 inhibition on expression of expansion-related genes in cultured COCs. The relative abundance of specific gene mRNA was measured in COCs cultured in medium supplemented with $20 \mu \mathrm{M}$ SB203580 for $4 \mathrm{~h}$ and is expressed in arbitrary units as fold strength increases in specific gene/HPRT1 ratio over the level found in COCs cultured with FSH or AREG. Different superscripts above the columns indicate significant differences $(P<0.05)$.

(Fig. 5B). To exclude a possibility that the drug only postponed maturation of oocytes, we extended the culture period to $48 \mathrm{~h}$. The result was, however, the same - almost all oocytes passed GVBD and remained blocked at MI stage at the end of culture (data not shown). A paradoxical effect of LY29004 on AREGinduced maturation of oocytes was repeatedly observed in our experiments: low concentrations of LY294002 $(5-10 \mu \mathrm{M})$ efficiently blocked maturation of oocytes at GV stage whereas high concentrations of LY294002 $(15-50 \mu \mathrm{M})$ allowed majority of the oocytes to undergo GVBD and blocked maturation in MI (Fig. 5B). No differences were observed in effect of LY294002 on FSH- and AREG-induced expansion of cumulus cells. The tested concentrations of the drug gradually inhibited cumulus expansion; $20 \mu \mathrm{M}$ LY294002 caused almost complete inhibition of expansion in both groups (Fig. 5C). Higher concentrations of LY294002 (25 and $50 \mu \mathrm{M})$ caused obvious degeneration of cumulus cells during $24 \mathrm{~h}$ of culture. The $24-\mathrm{h}$ exposure of COCs to
5-20 $\mu$ M LY294002 did not lead to irreversible changes and the COCs underwent expansion after washing the drug whereas exposure of the COCs to 25 or $50 \mu \mathrm{M}$ LY294002 caused irreversible damage and the COCs lost a capability to undergo expansion after washing (data not shown).

The LY294002 affected FSH- and AREG-induced expression of expansion-related genes in the same manner: it significantly inhibited expression of HAS2 and TNFAIP6 and significantly increased expression of PTGS2 (Fig. 5D).

\section{Discussion}

The preovulatory surge of gonadotropins causes activation of a broad cell-signaling network, which results in a dramatic change in gene expression and also posttranscriptional modifications in all compartments of the follicle. The signaling in granulosa and cumulus cell, also modified by signals from the oocyte, removes the 
A

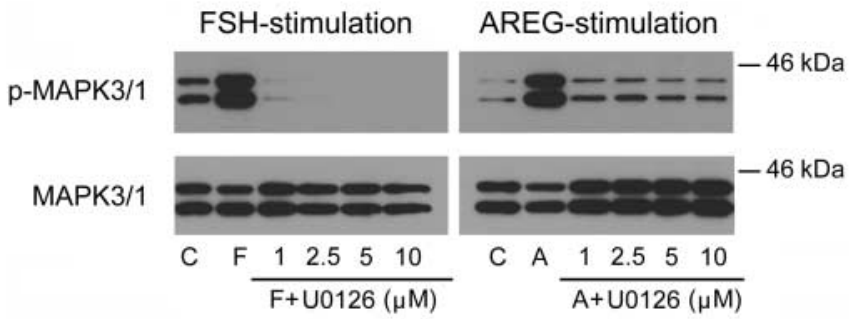

B

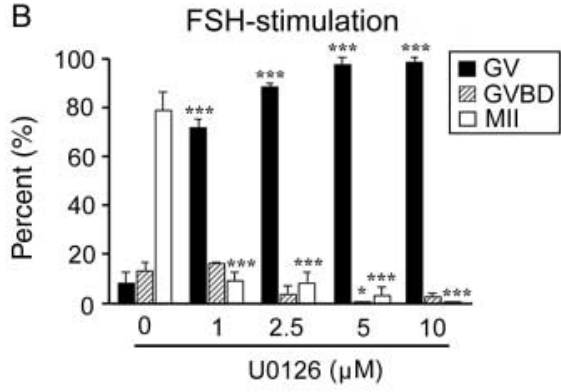

C

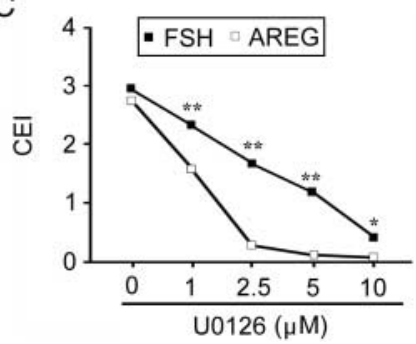

D
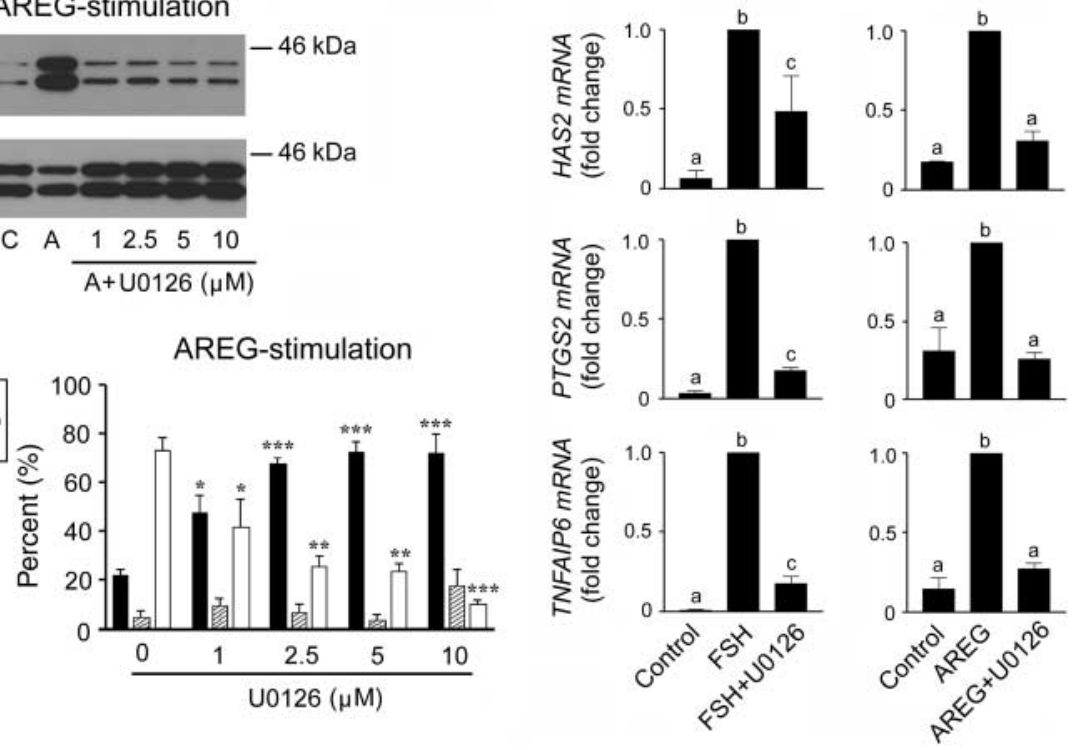

Figure 3 Effect of MAPK3/1 inhibition on meiotic resumption and cumulus cell expansion. (A) Effect of U0126 on activation of MAPK3/1 in cultured COCs. The panels display immunoblotting of phosphorylated and total MAPK3/1 in FSH- and AREG-stimulated COCs cultured for 3 or $1 \mathrm{~h}$ respectively in medium with different concentrations of $U 0126$. This experiment was repeated twice with similar results. C, control COCs cultured without stimulation; F, FSH; A, AREG. Position of molecular weight marker is on the right. (B) Maturation of oocytes in medium with different concentrations of U0126. Asterisks above the column indicate a significant difference from the corresponding control value found in oocytes cultured without U0126; ${ }^{*} P<0.05, * * P<0.01$, and ${ }^{* * *} P<0.001$. Approximately 90 COCs were included in each group. (C) Degree of cumulus expansion in COCs cultured in medium with different concentrations of U0126. Asterisks above the value mean significant difference from the corresponding value within the same concentration of $U 0126$; ${ }^{*} P<0.05$ and ${ }^{* *} P<0.01$. (D) Effect of MAPK3/1 inhibition on expression of expansion-related genes in cultured COCs. The relative abundance of specific gene mRNA was measured in COCs cultured in medium supplemented with $10 \mu \mathrm{M} \cup 0126$ for $4 \mathrm{~h}$ and is expressed in arbitrary units as fold strength increases in specific gene/HPRT1 ratio over the level found in COCs cultured with FSH or AREG. Different superscripts above the columns indicate significant differences $(P<0.05)$.

inhibitory influence of the follicle on the oocyte cell cycle and meiosis can resume (Sun et al. 2009, Conti et al. 2012).

The present results show a critical importance of PKA in regulation of $\mathrm{FSH}$-induced meiotic resumption in pig oocytes. In the mouse, an increase in cAMP concentration and PKA activity is a prerequisite for gonadotropin-induced activation of MAPK3/1 in cumulus cells and induction of meiotic resumption (Su et al. 2002). Next, the cAMP/PKA signaling is crucial for production of EGF-like factors and transactivation of the EGFR in mouse follicles (Conti et al. 2006) and also for expression of AREG and EREG in cultured human ovarian cells (Freimann et al. 2004, Ben-Ami et al. 2006). Thus, it appears that a principal role of PKA toward resumption of meiosis in the preovulatory mammalian follicle is propagation of the gonadotropin signals in mural granulosa cells leading to transition of the signals to cumulus cell and reentry of the oocyte into the meiotic cell cycle. The results of our study support this idea as inhibition of PKA blocked only FSH-stimulated resumption of meiosis but was not able to block the resumption stimulated by AREG. Thus, the PKA appears to work in pig COCs upstream of AREG production.

Under in vitro conditions, FSH induces expansion of cumulus cells in all studied mammalian species. The $\mathrm{FSH}$-induced expansion is preceded by an increase in cAMP concentration in cumulus cells and increased expression of HAS2 (Salustri 2000). The expansion can also be induced by forskolin, a direct activator of adenylate cyclase, or 8-Br-cAMP, a membrane permeable analog of cAMP (Su et al. 2002). All these data suggest that CAMP signaling is involved in physiological mechanisms regulating cumulus cell expansion. 
A

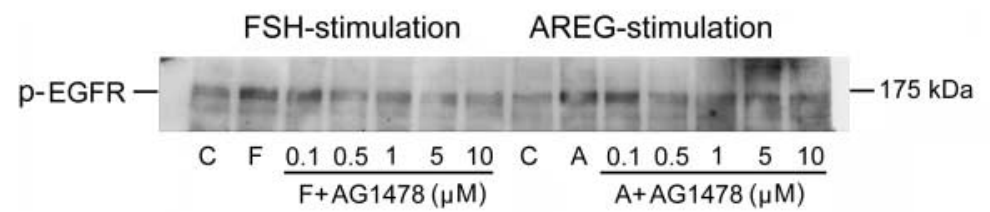

B FSH-stimulation

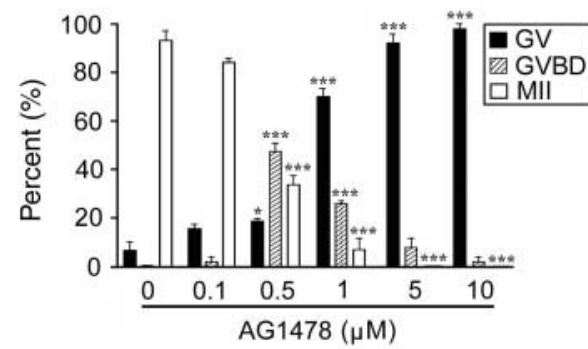

C

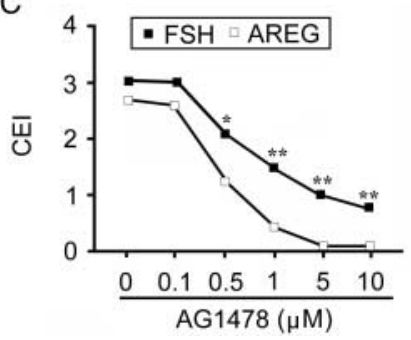

D
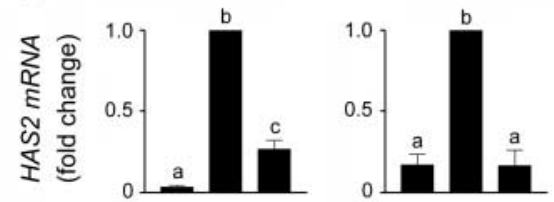

AREG-stimulation
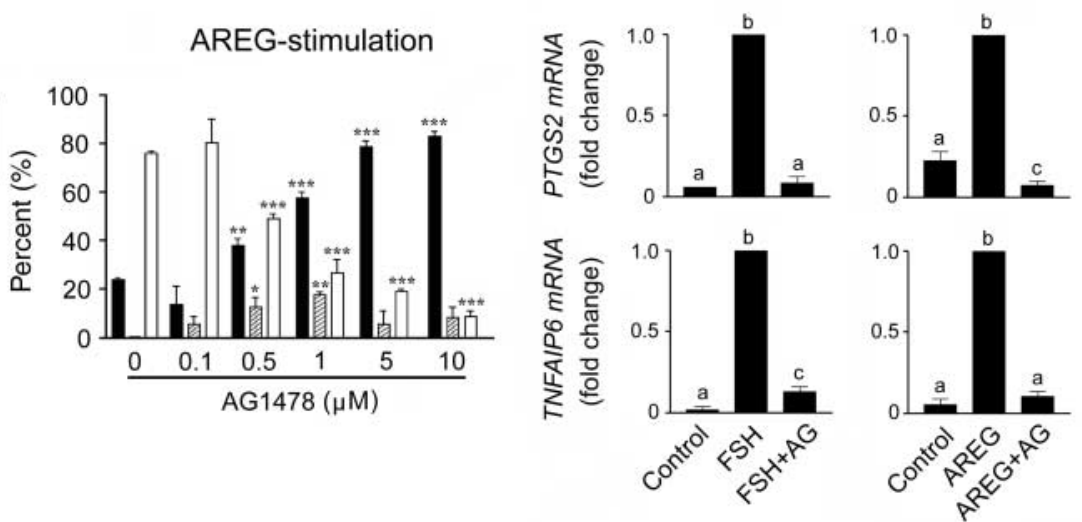

Figure 4 Effect of EGFR tyrosine kinase inhibition on meiotic resumption and cumulus cell expansion. (A) Effect of AG1478 on phosphorylation of the EGFR in cultured COCs. The panels display phosphorylation of the EGFR on tyrosine residues in FSH- and AREG-stimulated COCs cultured for 15 min in medium with different concentrations of AG1478. This experiment was repeated twice with similar results. C, control COCs cultured without stimulation; F, FSH; A, AREG. Position of molecular weight marker is on the right. (B) Maturation of oocytes in medium with different concentrations of AG1478. Asterisks above the column indicate a significant difference from the corresponding control value found in oocytes cultured without AG1478; ${ }^{*} P<0.05,{ }^{*} P<0.01$, and ${ }^{* * *} P<0.001$. Approximately 90 COCs were included in each group. (C) Degree of cumulus expansion in COCs cultured in medium with different concentrations of AG1478. Asterisk above the value means significant difference from the corresponding value within the same concentration of U0126; ${ }^{*} P<0.05$ and ${ }^{* *} P<0.01$. (D) Effect of EGFR tyrosine kinase inhibition on expression of expansion-related genes in cultured COCs. The relative abundance of specific gene mRNA was measured in COCs cultured in medium supplemented with $10 \mu \mathrm{M}$ AG1478 for $4 \mathrm{~h}$ and is expressed in arbitrary units as fold strength increases in specific gene/HPRT1 ratio over the level found in COCs cultured with FSH or AREG. Different superscripts above the columns indicate significant differences $(P<0.05)$.

However, recent data suggest that PKA is not the only transmitter of the cAMP signals in mammalian cell. The PKA-independent CAMP signaling has recently been reported in rat granulosa cells (Gonzalez-Robayna et al. 2000, Wayne et al. 2007). The data of our study indicate that PKA is not the principal kinase regulating FSHinduced expansion of cumulus cells in the pig. Inhibition of PKA did not decrease FSH-stimulated expression of $H A S 2$, the key enzyme regulating synthesis of hyaluronic acid, but significantly decreased expression of TNFAIP6, which is involved in stabilization of the hyaluronic acid in the matrix (Salustri 2000, Fulop et al. 2003, Nagyova et al. 2009). The PKA inhibition may thus adversely affect cumulus expansion by compromising the stability of the matrix rather than limiting its production by the cumulus cells. The AREG-induced expression of the HAS2 and PTGS2 was not affected by PKA inhibition at all, which is in correspondence with our finding that the EGF-like factors do not activate PKA (Prochazka et al. 2011; this study), but surprisingly reduced expression of TNFAIP6. The inhibition of TNFAIP6 was conceivably the reason why $\mathrm{H} 89$ inhibited degree of expansion not only in the FSH-stimulated COCs but also in the AREG-stimulated COCs.

MAPK14 was first characterized as a kinase responding to different environmental stress stimuli and inflammatory cytokines and regulating cell proliferation, differentiation, motility, and apoptosis. In addition, recent experiments disclosed an involvement of this kinase in transduction of gonadotropin-induced signals in somatic follicular cells (Villa-Diaz \& Miyano 2004, Diaz et al. 2006, Shimada et al. 2006). The results of our study revealed high sensitivity of the FSH-stimulated meiotic resumption and low sensitivity of the AREGstimulated meiotic resumption to the MAPK14 inhibitor, indicating an important role of MAPK14 upstream of AREG production. Indeed, MAPK14 has been reported to be involved in FSH-stimulated initial production of 
A
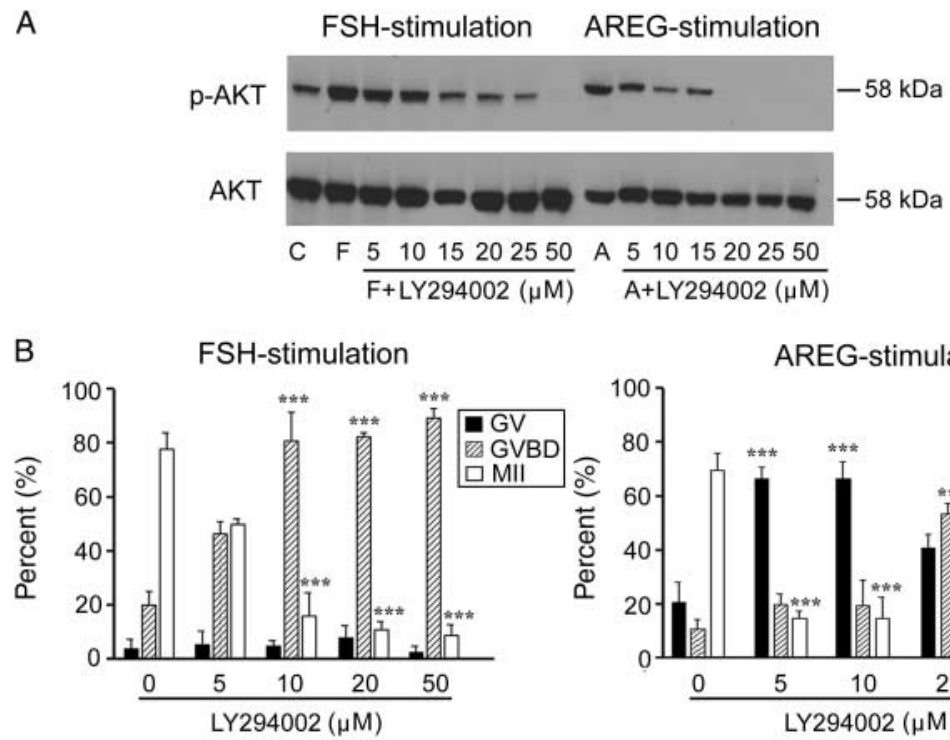

C

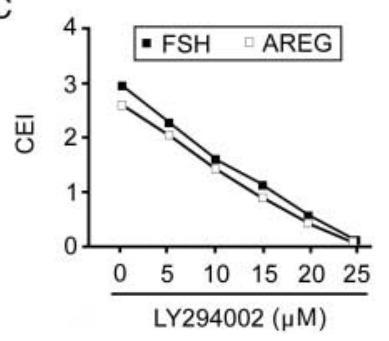

D
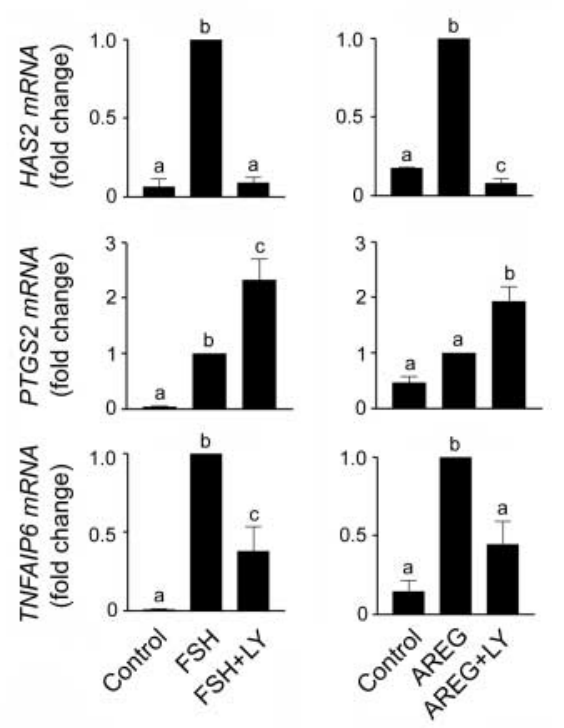

Figure 5 Effect of PI3K/AKT inhibition on meiotic resumption and cumulus cell expansion. (A) Effect of LY294002 on activation of AKT in cultured COCs. The panels display immunoblotting of phosphorylated and total AKT in FSH-and AREG-stimulated COCs cultured for $1 \mathrm{~h}$ in medium with different concentrations of LY294002. This experiment was repeated twice with similar results. C, control COCs cultured without stimulation; F, FSH; A, AREG. Position of molecular weight marker is on the right. (B) Maturation of oocytes in medium with different concentrations of LY294002. Asterisks above the column indicate a significant difference from the corresponding control value found in oocytes cultured without LY294002; ${ }^{* *} P<0.01$ and ${ }^{* * *} P<0.001$. Approximately 90 COCs were included in each group. (C) Degree of cumulus expansion in COCs cultured in medium with different concentrations of LY294002. (D) Effect of PI3K/AKT inhibition on expression of expansion-related genes in cultured COCs. The relative abundance of specific gene mRNA was measured in COCs cultured in medium supplemented with $25 \mu \mathrm{M} \mathrm{LY} 294002$ for $4 \mathrm{~h}$ and is expressed in arbitrary units as fold strength increases in specific gene/HPRT1 ratio over the level found in COCs cultured with FSH or AREG. Different superscripts above the columns indicate significant differences $(P<0.05)$.

Areg in cultured mouse COCs that precedes activation of EGFR and MAPK3/1-dependent induction of the expansion-related genes (Shimada et al. 2006). We may thus speculate that similar FSH-induced and MAPK14-dependent production of AREG also occurs in pig COCs and that the initial and rapid production of AREG plays an important role in induction of meiotic resumption. A possible target of such signaling pathway might be the regulation of gap junctions closure within the cumulus compartment that occurs soon after gonadotropin stimulation, plays a crucial role in meiotic resumption, and requires participation of EGF-like factors (Sela-Abramovich et al. 2005, Norris et al. 2008, Vaccari et al. 2009). Moreover, our results indicate that MAPK14 may also be required for completion of meiosis. In agreement with this observation, MAPK14 was found active in pig oocytes during MI/MII transition (Villa-Diaz \& Miyano 2004).
MAPK14 was reported to play an important role in a paracrine- and autocrine-positive feedback loop between mouse granulosa and cumulus cells, in which prostaglandin E2 (PGE2), through PGE2 receptor and MAPK14, enhances expression of EGF-like factors that stimulate expression of the expansion-related genes, inclusive of PTGS2, a major regulator of PGE2 synthesis (Shimada et al. 2006). Therefore, through this mechanism, the MAPK14 is involved in regulation of mouse cumulus expansion. Such a MAPK14-dependent regulatory loop seems to also work in the pig as indicated by results presented in this study and also in other studies reporting inhibition of pig cumulus expansion by SB203580 (Yamashita et al. 2009, Gilchrist \& Ritter 2011). In the mouse, FSH- but not EGF-induced cumulus expansion and elevation of expansion-related transcripts (Has2 and Ptgs2) required MAPK14 activity (Diaz et al. 2006). We have observed similar differences 
between FSH and AREG stimulation in relation to meiotic resumption but the expansion-related events were suppressed by MAPK14 inhibitor irrespective of the mode of stimulation in this study. The reason of this discrepancy is not clear, but it is not associated with a different role of oocyte-derived factors in regulation of cumulus expansion in the mouse and pig (Prochazka et al. 1991, Vanderhyden 1993), as these factors act in mouse cumulus cells downstream of MAPK14 activation (Diaz et al. 2006). Interestingly, mice with granulosa cellspecific knockout of the MAPK $14 \alpha$ isoform displayed an aberrant cumulus expansion in vitro whereas in vivo expansion of cumulus and ovulation occurs normally (Liu et al. 2010). The significance of MAPK14 signaling for in vivo oocyte maturation and ovulation is not known in other species and should be studied.

The transactivation of the EGFR and activation of the MAPK3/1 pathway in follicular somatic cells are considered to be important steps in gonadotropininduced cumulus expansion and oocyte maturation (Su et al. 2002, Park et al. 2004, Conti et al. 2006, Shimada et al. 2006, Fan et al. 2009). In rat follicles, MAPK3/1 mediates the LH-induced breakdown of cellto-cell communication, possibly by phosphorylation of connexin 43 (Sela-Abramovich et al. 2005). The drop in the intercellular communication is necessary for meiosis reinitiation and is supposed to limit transfer of meiosis blocking substances to the oocyte. In the mouse, activation of EGFR is involved in $\mathrm{LH}$-induced decrease in cGMP transport from granulosa and cumulus cells to the oocyte and both EGFR and MAPK3/1 activities participate in gap junction closure (Vaccari et al. 2009, Norris et al. 2009, 2010, Hsieh et al. 2011). These mechanisms contribute to relieve meiotic block as cGMP works in oocytes as a natural inhibitor of phosphodiesterase $3 \mathrm{~A}$, maintaining high intracellular level of CAMP and meiotic arrest of the oocyte (Masciarelli et al. 2004). In the pig, activation of MAPK3/1 in cumulus cells is also a prerequisite for gonadotropin-stimulated resumption of meiosis (Meinecke \& Krischek 2003, Liang et al. 2005, Li et al. 2008). In this study, we show that both FSH- and AREGinduced resumption of meiosis in pig oocytes is dependent on EGFR and MAPK3/1 activity, which supports the idea that also in pig COCs, FSH drives resumption of meiosis by transactivation of the EGFR and activation of MAPK3/1 in the cumulus cells.

EGFR tyrosine kinase and MAPK3/1 activities are crucial for expansion of cumulus cells in different species including the pig (Prochazka et al. 2003, Chen et al. 2008, Nagyova et al. 2011). Nevertheless, the data of this study indicate that EGFR/MAPK3/1 pathway is not the only pathway controlling gonadotropininduced expression of the expansion-related genes, at least in the in vitro system. First, FSH induced much greater increase in HAS2, PTGS2, and TNFAIP6 expression in the cultured COCs than AREG (see also
Prochazka et al. (2011)). Secondly, AG1478 and U0126 completely inhibited the AREG-induced expression of the expansion-related genes on a level comparable with the control non-stimulated COCs, but the FSHstimulated expression of the genes was only partially decreased by these inhibitors. Thirdly, the FSHstimulated COCs were less sensitive to AG1478 than the AREG-stimulated COCs regarding the degree of expansion assessed by CEI. The complete inhibition of EGF-stimulated cumulus expansion and only partial decrease of FSH-stimulated expansion by AG1478 were reported previously in the pig (Chen et al. 2008).

The involvement of PI3K/AKT signaling in meiotic resumption and cumulus cells expansion has been extensively studied in the pig. An incentive for these studies was a finding that insulin-like growth factor 1 , a known activator of PI3K/AKT signaling, is the component of serum that enables expansion of pig cumulus cells in vitro in response to FSH (Singh \& Armstrong 1997). Further studies have revealed that PI3K/AKT signaling is involved in regulation of connexin 43 phosphorylation (Shimada et al. 2001) and in promotion of $\mathrm{FSH}$-stimulated synthesis and retention of hyaluronic acid in pig COCs (Nagyova et al. 1999, Nemcova et al. 2007). Inhibition of PI3K/AKT signaling in matured pig COCs by LY294002 showed interesting differences between FSH- and AREG-induced maturation in our study. FSH-stimulated oocytes were arrested at MI stage whereas AREG-stimulated oocytes were blocked in GV by low concentrations of the inhibitor whereas high concentrations of the inhibitor led to resumption of meiosis and interruption of oocyte maturation at $\mathrm{Ml}$ stage. Thus, $\mathrm{FSH}$-induced resumption of meiosis does not seem to be regulated by PI3K/AKT, but this pathway appears important for progression of meiosis to MI/MII stage. This observation is in agreement with previous studies in the pig (Shimada et al. 1988, Kalous et al. 2009). The mechanism of the interruption of meiosis may consist in increased activity of glycogen synthase kinase 3 in centrosomal region, which leads to formation of aberrant MI spindles (Kalous et al. 2009). The AREG-stimulated resumption of oocyte maturation, however, seems to be dependent on PI3K/AKT activity in cumulus cells as shown in our study and also in another study carried out on the pig model (Li et al. 2008). The failure of high concentrations of LY29004 to block AREG-induced meiotic resumption observed in our study can be explained by a damage of the surrounding cumulus cells that are undoubtedly involved in that inhibitory mechanism. The damage of cumulus cells was displayed in our experiments by a lack to undergo expansion after washing and it was also documented by high incidence of apoptotic cells in cumuli treated by high doses of LY294002 (Shimada et al. 2003).

PI3K/AKT activity is required for gonadotropininduced expansion of pig cumulus cells in vitro (Shimada et al. 1988, 2001, Nemcova et al. 2007). 
The data of this study show that AREG-induced expansion is also sensitive to PI3K/AKT inhibition. No differences between FSH and AREG were found regarding the degree of expansion expressed by CEI and also the effect on expression of expansion-related genes was very similar. Interestingly, the expression of PTGS2 was increased in both groups by the LY294002 whereas the expression of the other genes was decreased. The mechanism of the stimulatory effect of LY294002 on PTGS2 expression is not known and should be studied in further experiments.

The results of this study are summarized in Fig. 6 and document that FSH-stimulated, but not the AREGstimulated, resumption of meiosis depends on the PKA and MAPK14 activities; both modes of stimulation require activation of EGFR and MAPK3/1. Taken together, these results are consistent with the idea that PKA and MAPK14 pathways are essential for FSHinduced transactivation of the EGFR and synthesis of EGF-like peptides. On the other hand, EGFR tyrosine kinase and MAPK3/1 activities in cumulus cells are involved in regulation of transcriptional and posttranscriptional events required for resumption of oocyte meiosis. PI3K/AKT signaling is important for regulation of MI/MII transition and AREG-induced GVBD. Both FSH- and AREG-induced expression of the expansionrelated genes was dependent on MAPK14 and MAPK3/1, and with exception for PTGS2 also on PI3K/AKT activity.
Interestingly, the FSH-induced expression of the HAS2 and PTGS2, but not that of TNFAIP6, was driven by a PKA-independent pathway that should be defined in future experiments.

\section{Materials and Methods \\ Isolation and culture of COCs}

Ovaries of slaughtered gilts were collected at a local abattoir and transported to the laboratory in a thermos at $37^{\circ} \mathrm{C}$. The contents of the medium size follicles (3-6 mm in diameter) was aspirated by a syringe connected with a $20 \mathrm{G}$ needle, pooled in a Petri dish, and washed twice with PBS. COCs were picked out from the diluted aspirate and washed in the PBS. Only COCs surrounded by compact multi-layered cumulus were selected for experiments. About 30 COCs were cultured in $0.5 \mathrm{ml}$ medium M-199 (Gibco, Life Technologies) supplemented with $0.91 \mathrm{mM}$ sodium pyruvate, $0.57 \mathrm{mM}$ cysteine, $2.3 \mathrm{mM}$ HEPES, antibiotics, and 5\% FCS (Sigma). The COCs were cultured in four-well dishes (Nunclon, Roskilde, Denmark) at $38.5^{\circ} \mathrm{C}$ in a humidified atmosphere of $5 \% \mathrm{CO}_{2}$ in the air. The maturation of oocytes and expansion of cumulus cells were stimulated by the addition of ovine pituitary FSH ( $1 \mathrm{IU} / \mathrm{ml}$; \#F8174; Sigma) or recombinant human AREG (100 ng/ml; \#A7080; Sigma) into the culture medium. The FSH and AREG were dissolved in PBS according to the manufacturer's instructions and working aliquots were stored at $-20^{\circ} \mathrm{C}$ for up to 3 months. For inhibition of PKA, MAPK14, MAPK3/1, EGFR tyrosine kinase, and PI3K/AKT, the COCs were first exposed for $1 \mathrm{~h}$ to different

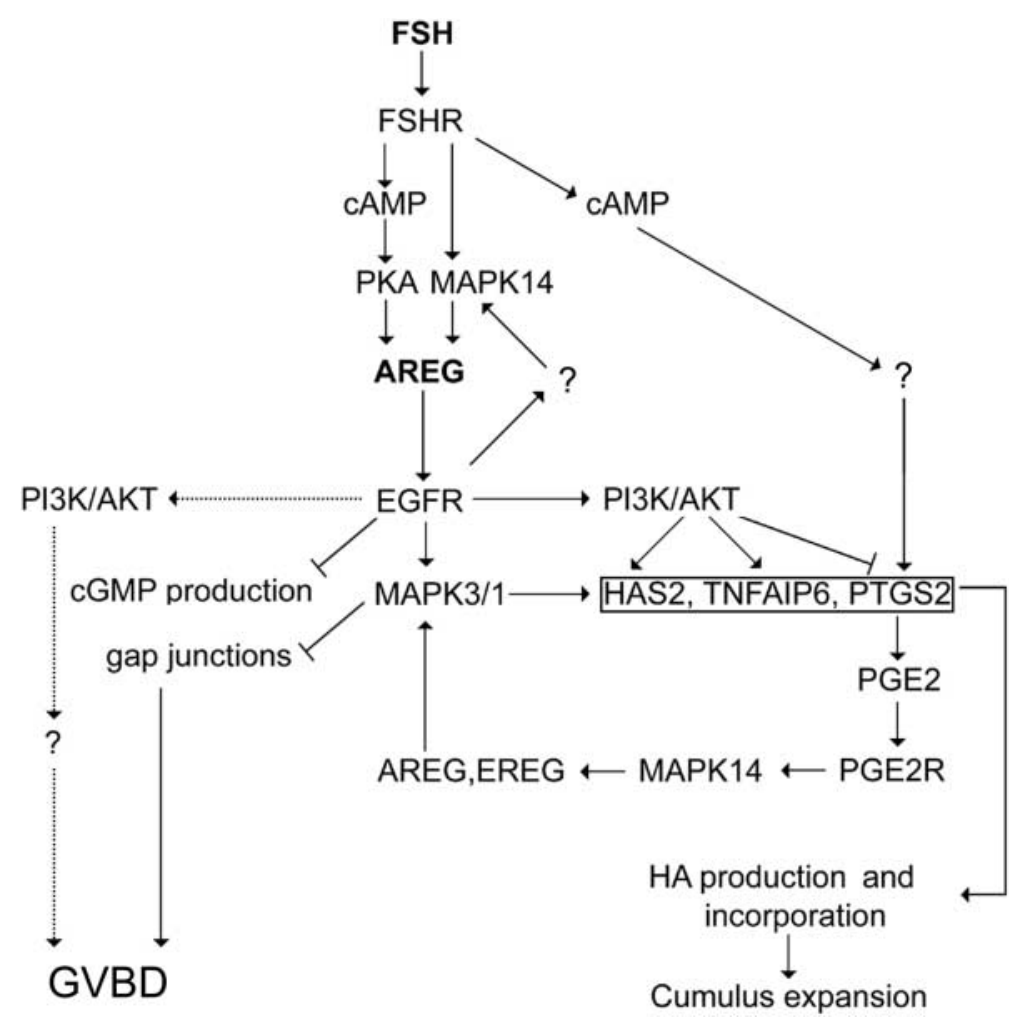

Figure 6 Scheme of signaling pathways activated in pig cumulus cells by FSH and AREG under in vitro conditions. The scheme summarizes data of this study in context of our current knowledge on regulation of meiotic resumption and cumulus cell expansion. The signaling pathway drawn in dotted line was activated only by exogenous AREG. The regulatory loop between EGFR and MAPK14 appears important only for cumulus expansion and might represent part of the FSH-stimulated but PKA-independent mechanism regulating expression of the expansion-related genes; the second part of this mechanism seems to be independent of both PKA and EGFR activity. Question marks indicate unidentified links. 
concentrations of H89 (Sigma), SB203580 (Merck Chemicals Ltd.), U0126 (Merck Chemicals Ltd.), AG1478 (Sigma), or LY294002 (Sigma) respectively and then FSH or AREG was added. The inhibitors were dissolved in dimethyl sulfoxide (DMSO) and 10 or $100 \mathrm{mM}$ stocks were stored frozen at $-20{ }^{\circ} \mathrm{C}$ for a maximum period of 3 months. The maximum final concentration of DMSO in culture medium was $0.2 \%(\mathrm{v} / \mathrm{v})$.

\section{Assessment of oocyte maturation and cumulus cell expansion}

To assess the nuclear maturation, oocytes were cultured for $42 \mathrm{~h}$ and then removed of cumulus cells by vortexing, mounted on slides, and fixed in acetic ethanol for $48 \mathrm{~h}$. Oocytes were then stained with $1 \%$ orcein and observed with a light microscope. Oocytes were scored for GV, GVBD (comprising mostly oocytes at MI stage and few oocytes at late diakinesis, anaphase I or telophase I), and for MII stage. The degree of cumulus expansion was assessed at $24 \mathrm{~h}$ after the onset of culture using a subjective scoring method (Vanderhyden et al. 1993). Briefly, no response is scored as 0 , minimum observable response, the cells in outermost layer of the cumulus become round and glistening as 1 , the expansion of outer COCs layers as 2, the expansion of all COCs layers except corona radiata as 3, and the expansion of all COCs layers as 4. Afterward, a CEI (0-4) was calculated as an average degree of expansion in the experimental group of COCs.

\section{Real-time RT-PCR}

Based on our previous results (Prochazka et al. 2011), the expression of the expansion-related genes was assessed at $4 \mathrm{~h}$ after the onset of COC stimulation. Total RNA from 30 COCs was extracted with the use of an RNeasy Mini Kit (Qiagen) following the manufacturer's instructions. RNA was eluted in $50 \mu \mathrm{l}$ RNase-free water and stored at $-80^{\circ} \mathrm{C}$. The concentration of total RNA in samples was measured by a spectrophotometer NanoDrop ND-1000 (NanoDrop Technologies, Wilmington, DE, USA).

The relative abundance of HAS2, TNFAIP6, and PTGS2 mRNA in pig COCs was assessed by a real-time RT-PCR using a One-Step RT-PCR Kit (Qiagen) and primers designated for the specific sequences (Table 1). The total RNA of the samples was reverse transcribed and subsequently amplified in a reaction mixture (total volume $25 \mu \mathrm{l}$ ) containing $5 \mu \mathrm{l} 5 \times$ reaction buffer, $1 \mu \mathrm{l}$ dNTP mix (10 mM stock of each), $0.5 \mu \mathrm{l}$ of both reverse and forward primers (0.02 $\mathrm{mM}$ stock), $0.15 \mu \mathrm{l}$ RNasine (20 U/ $\mu$ l stock; Promega), $1 \mu \mathrm{l}$ enzyme mix, and $4 \mu \mathrm{l}$ RNA. In addition, $0.5 \mu \mathrm{l}$ SYBR Green I of $1: 1000 \times$ stock solution (Molecular Probes, Eugene, OR, USA) was added in each reaction. The amplification was performed on the RotorGene 3000 cycler (Corbett Research, Sydney, Australia). The reaction conditions were as follows: cDNA synthesis at $50{ }^{\circ} \mathrm{C}$ for $30 \mathrm{~min}$, pre-denaturation at $95^{\circ} \mathrm{C}$ for $15 \mathrm{~min}$, followed by various numbers of PCR cycles consisting of denaturation $\left(95^{\circ} \mathrm{C}\right.$ for $\left.15 \mathrm{~s}\right)$, annealing $(20 \mathrm{~s})$ at temperature specific for each set of primers (Table 1$)$, extension $\left(72{ }^{\circ} \mathrm{C}\right.$ for $20 \mathrm{~s}$ ), and final extension at $72{ }^{\circ} \mathrm{C}$ for $5 \mathrm{~min}$. Fluorescence data were acquired during an additional step at $\sim 3{ }^{\circ} \mathrm{C}$ below the product's melting temperature. After the cycling, the melting curve was generated to verify the amplification of one specific target (one peak at a specific melting temperature demonstrates the specificity). In addition, gel electrophoresis and ethidium bromide staining assessed the specificity of RT-PCR products.

The relative concentration of templates in different samples was determined using comparative analysis software (Corbett Research). The results for individual target messages were normalized according to the relative concentration of the internal standard, the HPRT1 (HPRT).

\section{PKA activity assay}

PKA activity was assessed by a PepTag Assay for NonRadioactive Detection of cAMP-Dependent Protein Kinase kit (Promega) according to the manufacturer's instructions. Unless otherwise indicated, 50 COCs were cultured for $1 \mathrm{~h}$ and then stored frozen at $-70{ }^{\circ} \mathrm{C}$ in a minimum volume of PBS until use in the assay. The samples were lysed in $10 \mu \mathrm{l}$ cell lysis buffer (Cell Signaling Technology, Danvers, MA, USA) and mixed in a test tube with $5 \mu \mathrm{l}$ PKA reaction buffer (100 mM Tris, $\mathrm{pH} 7.4$, $50 \mathrm{mM} \mathrm{MgCl}_{2}$, and $5 \mathrm{mM} \mathrm{ATP),} 5 \mu \mathrm{l}$ PKA-specific fluorescent peptide substrate (Kemptide, $0.4 \mu \mathrm{g} / \mu \mathrm{l}$ stock), and $5 \mu \mathrm{l}$ deionized water. Negative control assay was run without the cell sample; in positive control assays, the sample was substituted with $25 \mathrm{ng}$ catalytic subunit of PKA (diluted in $5 \mu 350 \mathrm{mM} \mathrm{K}_{3} \mathrm{PO}_{4}$ with $0.1 \mathrm{mM}$ dithiothreitol) and $5 \mu \mathrm{IKA}$ activator solution ( $5 \mu \mathrm{M}$ CAMP in water). The reaction mixture was incubated at room temperature for $30 \mathrm{~min}$ and then stopped by placing the test tubes in boiling water for $10 \mathrm{~min}$. The samples were loaded into the wells in $0.8 \%$ agarose gel and run at $100 \mathrm{~V}$ for $15 \mathrm{~min}$. The phosphorylated substrate migrated toward the positive electrode while the nonphosphorylated substrate migrated toward the negative

Table 1 Primers used for real-time RT-PCR.

\begin{tabular}{|c|c|c|c|c|}
\hline Gene transcript & Primers & $\begin{array}{l}\text { Amplicon } \\
\text { length (bp) }\end{array}$ & $\mathbf{T}_{\mathrm{an}}\left({ }^{\circ} \mathrm{C}\right)$ & $\begin{array}{l}\text { GenBank accession } \\
\text { number }\end{array}$ \\
\hline HAS2 & $\begin{array}{l}\text { F: 5'-GAA GTC ATG GGC AGG GAC AAT TC-3' } \\
\text { R: 5'-TGG CAG GCC CTT TCT ATG TTA-3' }\end{array}$ & 407 & 54 & NM_214053 \\
\hline PTGS2 & $\begin{array}{l}\text { F: 5'-TCG ACC AGA GCA GAG AGA TGA GAT-3' } \\
\text { R: 5'-ACC ATA GAG CGC TTC TAA CTC TGC-3' }\end{array}$ & 260 & 55 & NM_214321 \\
\hline TNFAIP6 & $\begin{array}{l}\text { F: 5'-TCA TAA CTC CAT ATG GCT TGA AC- } 3^{\prime} \\
\text { R: } 5^{\prime} \text {-TCT TCG TAC TCA TTT GGG AAG CC- } 3^{\prime}\end{array}$ & 396 & 54 & Yamashita et al. (2009) \\
\hline HPRT1 & $\begin{array}{l}\text { F: 5'-CCA GTC AAC GGG CGA TAT AA-3' } \\
\text { R: 5'-CTT GAC CAA GGA AAG CAA GG-3' }\end{array}$ & 129 & 55 & NM_001032376 \\
\hline
\end{tabular}

$\mathrm{T}_{\mathrm{an}}$, annealing temperature. 
electrode. The gel was photographed in u.v. light and the images were assessed for the proportions of phosphorylated and non-phosphorylated substrate.

\section{Immunoblotting}

Groups of 25-50 COCs were lysed in $15 \mu \mathrm{l}$ Laemmli sample buffer for SDS-PAGE, heated at $100{ }^{\circ} \mathrm{C}$ for $3 \mathrm{~min}$, and stored at $-80{ }^{\circ} \mathrm{C}$. The proteins of the samples were separated on $712 \%$ polyacrylamide gel and transferred to PVDF membrane (Immobilon-P, Millipore, Bedford, MA, USA). The MAPK14 activity was assessed as described by Villa-Diaz \& Miyano (2004). For the other protein detections, membranes were blocked in 5\% low-fat dry milk or 10\% FCS (PY20) in Trisbuffered saline (TBS) with $0.5 \%$ of Tween 20 for $2 \mathrm{~h}$ at room temperature and then incubated with primary antibody diluted $1: 1000$ in $5 \%$ BSA in TBS-Tween at $4{ }^{\circ} \mathrm{C}$ overnight. The following primary antibodies were used: phospho-AKT (Ser 473), AKT - both from Cell Signaling Technology, p-ERK, ERK (detecting MAPK3/1) - both from Santa Cruz Biotechnology (Santa Cruz, CA, USA), phospho-p38 MAPK, p38 MAPK (detecting MAPK14) - both from Cell Signaling, and antiphosphotyrosine antibody PY20 from BioLegend (San Diego, CA, USA). The secondary antibody (anti-mouse or anti-rabbit IgG conjugated with HRP; GE Healthcare, Little Chalfont, UK) was diluted 1:5000 in 2\% BSA in TBS-Tween. The membranes were incubated with the secondary antibody for $1 \mathrm{~h}$ at room temperature and washed intensively in TBS-Tween. The immune reaction was detected by ECL (Pierce, Rockford, IL, USA) according to the manufacturer's instructions. Following detection, the antibodies were stripped by incubation of the membrane in $25 \mathrm{mM}$ Tris with $2 \% \beta$-mercaptoethanol and $0.2 \%$ SDS at $60{ }^{\circ} \mathrm{C}$ for $20 \mathrm{~min}$ and reprobed with the next primary antibody.

\section{Statistical analysis}

Unless otherwise indicated, each experiment was performed in at least three replicates. Each replicate was performed on different day on a single batch of COCs that were randomly allocated to the treatments. The differences in percentages of maturing oocytes and the quantifications of RT-PCR results were compared by the ANOVA followed by Tukey's posttest. The differences of CEI between FSH- and AREG-stimulated COCs were performed by $\chi^{2}$ analysis. Error bars indicate the S.E.M.

\section{Declaration of interest}

The authors declare that there is no conflict of interest that could be perceived as prejudicing the impartiality of the research reported.

\section{Funding}

This work was supported by Grant Agency of the Czech Republic (grant P502/11/0593) and Ministry of Agriculture of the Czech Republic (grant QI 101A166).

\section{References}

Akaki Y, Yoshioka K, Noguchi M, Hoshi H \& Funahashi H 2009 Successful piglet production in a chemically defined system for in-vitro production of porcine embryos: dibutyryl cyclic AMP and epidermal growth factorfamily peptides support in-vitro maturation of oocytes in the absence of gonadotropins. Journal of Reproduction and Development 55 446-453. (doi:10.1262/jrd.20219)

Ashkenazi H, Cao X, Motola S, Popliker M, Conti M \& Tsafriri A 2005 Epidermal growth factor family members: endogenous mediators of the ovulatory response. Endocrinology 146 77-84. (doi:10.1210/en. 2004-0588)

Ben-Ami I, Freimann S, Armon L, Dantes A, Strassburger D, Friedler S, Raziel A, Seger R, Ron-El R \& Amsterdam A 2006 PGE2 up-regulates EGF-like growth factor biosynthesis in human granulosa cells: new insights into the coordination between PGE2 and LH in ovulation. Molecular Human Reproduction 12 593-599. (doi:10.1093/molehr/ gal068)

Chen X, Zhou B, Yan J, Xu B, Tai P, Li J, Peng S, Zhang M \& Xia G 2008 Epidermal growth factor receptor activation by protein kinase $\mathrm{C}$ is necessary for $\mathrm{FSH}$-induced meiotic resumption in porcine cumulus-oocyte complexes. Journal of Endocrinology 197 409-419. (doi:10.1677/JOE-07-0592)

Conti M, Hsieh M, Park JY \& Su YQ 2006 Role of the epidermal growth factor network in ovarian follicles. Molecular Endocrinology 20 715-723. (doi:10.1210/me.2005-0185)

Conti M, Hsieh M, Musa Zamah A \& Oh JS 2012 Novel signaling mechanisms in the ovary during oocyte maturation and ovulation. Molecular and Cellular Endocrinology 356 65-73. (doi:10.1016/j.mce. 2011.11.002)

Diaz FJ, O'Brien MJ, Wigglesworth K \& Eppig JJ 2006 The preantral granulosa cell to cumulus cell transition in the mouse ovary: development of competence to undergo expansion. Developmental Biology 299 91-104. (doi:10.1016/j.ydbio.2006.07.012)

Downs SM \& Chen J 2008 EGF-like peptides mediate FSH-induced maturation of cumulus cell-enclosed mouse oocytes. Molecular Reproduction and Development 75 105-114. (doi:10.1002/mrd.20781)

Fan HY, Liu Z, Shimada M, Sterneck E, Johnson PF, Hedrick SM \& Richards JS 2009 MAPK3/1 (ERK1/2) in ovarian granulosa cells are essential for female fertility. Science 324 938-941. (doi:10.1126/science. 1171396)

Freimann S, Ben-Ami I, Dantes A, Ron-El R \& Amsterdam A 2004 EGF-like factor epiregulin and amphiregulin expression is regulated by gonadotropins/cAMP in human ovarian follicular cells. Biochemical and Biophysical Research Communications 324 829-834. (doi:10.1016/j. bbrc.2004.09.129)

Fulop C, Szanto S, Mukhopadhyay D, Bardos T, Kamath RV, Rugg MS, Day AJ, Salustri A, Hascall VC, Glant TT et al. 2003 Impaired cumulus mucification and female sterility in tumor necrosis factor-induced protein-6 deficient mice. Development 130 2253-2261. (doi:10.1242/ dev.00422)

Gilchrist RB \& Ritter LJ 2011 Differences in the participation of TGFB superfamily signalling pathways mediating porcine and murine cumulus cell expansion. Reproduction 142 647-657. (doi:10.1530/REP-11-0196)

Gonzalez-Robayna IJ, Falender AE, Ochsner S, Firestone GL \& Richards JS 2000 Follicle-stimulating hormone (FSH) stimulates phosphorylation and activation of protein kinase B (PKB/Akt) and serum and glucocorticoidinduced kinase (Sgk): evidence for A kinase-independent signaling by FSH in granulosa cells. Molecular Endocrinology 14 1283-1300. (doi:10.1210/me.14.8.1283)

Hsieh M, Thao K \& Conti M 2011 Genetic dissection of epidermal growth factor receptor signaling during luteinizing hormone-induced oocyte maturation. PLoS ONE 6 e21574. (doi:10.1371/journal.pone.0021574)

Kalous J, Kubelka M, Solc P, Susor A \& Motlik J 2009 AKT (protein kinase B) is implicated in meiotic maturation of porcine oocytes. Reproduction 138 645-654. (doi:10.1530/REP-08-0461)

Li M, Liang CG, Xiong B, Xu BZ, Lin SL, Hou Y, Chen DY, Schatten H \& Sun QY 2008 Pl3-kinase and mitogen-activated protein kinase in cumulus cells mediate EGF-induced meiotic resumption of porcine oocytes. Domestic Animal Endocrinology 34 360-371. (doi:10.1016/ j.domaniend.2007.10.001) 
Liang CG, Huo LJ, Zhong ZS, Chen DY, Schatten H \& Sun QY 2005 Cyclic adenosine $3^{\prime}, 5^{\prime}$-monophosphate-dependent activation of mitogenactivated protein kinase in cumulus cells is essential for germinal vesicle breakdown of porcine cumulus-enclosed oocytes. Endocrinology 146 4437-4444. (doi:10.1210/en.2005-0309)

Liu Z, Fan HY, Wang Y \& Richards JS 2010 Targeted disruption of Mapk14 $(\mathrm{p} 38 \mathrm{MAPK} \alpha)$ in granulosa cells and cumulus cells causes cell-specific changes in gene expression profiles that rescue COC expansion and maintain fertility. Molecular Endocrinology 24 1794-1804. (doi:10.1210/me.2010-0086)

Masciarelli S, Horner K, Liu C, Park SH, Hinckley M, Hockman S, Nedachi T, Jin C, Conti M \& Manganiello V 2004 Cyclic nucleotide phosphodiesterase $3 \mathrm{~A}$-deficient mice as a model of female infertility. Journal of Clinical Investigation 114 196-205. (doi:10.1172/JCI200 421804)

Meinecke B \& Krischek C 2003 MAPK/ERK kinase (MEK) signalling is required for resumption of meiosis in cultured cumulus-enclosed pig oocytes. Zygote 11 7-16. (doi:10.1017/S0967199403001023)

Nagyova E, Prochazka R \& Vanderhyden BC 1999 Oocytectomy does not influence synthesis of hyaluronic acid by pig cumulus cells: retention of hyaluronic acid after insulin-like growth factor-I treatment in serumfree medium. Biology of Reproduction 61 569-574. (doi:10.1095/ biolreprod61.3.569)

Nagyova E, Nemcova L \& Prochazka R 2009 Expression of tumor necrosis factor $\alpha$-induced protein 6 messenger RNA in porcine preovulatory ovarian follicles. Journal of Reproduction and Development 55 231-235. (doi:10.1262/jrd.20115)

Nagyova E, Camaioni A, Scsukova S, Mlynarcikova A, Prochazka R, Nemcova L \& Salustri A 2011 Activation of cumulus cell SMAD 2/3 and epidermal growth factor receptor pathways are involved in porcine oocyte-cumulus cell expansion and steroidogenesis. Molecular Reproduction and Development 78 391-402. (doi:10.1002/mrd.21312)

Nemcova L, Nagyova E, Petlach M, Tomanek M \& Prochazka R 2007 Molecular mechanisms of insulin-like growth factor 1 promoted synthesis and retention of hyaluronic acid in porcine oocyte-cumulus complexes. Biology of Reproduction 76 1016-1024. (doi:10.1095/ biolreprod.106.057927)

Norris RP, Freudzon M, Mehlmann LM, Cowan AE, Simon AM, Paul DL, Lampe PD \& Jaffe LA 2008 Luteinizing hormone causes MAP kinasedependent phosphorylation and closure of connexin 43 gap junctions in mouse ovarian follicles: one of two paths to meiotic resumption. Development 135 3229-3238. (doi:10.1242/dev.025494)

Norris RP, Ratzan WJ, Freudzon M, Mehlmann LM, Krall J, Movsesian MA, Wang H, Ke H, Nikolaev VO \& Jaffe LA 2009 Cyclic GMP from the surrounding somatic cell regulates cyclic AMP and meiosis in the mouse oocyte. Development 136 1869-1878. (doi:10.1242/dev.035238)

Norris RP, Freudzon M, Nikolaev VO \& Jaffe LA 2010 Epidermal growth factor receptor kinase activity is required for gap junction closure and for part of the decrease in ovarian follicle cGMP in response to $\mathrm{LH}$. Reproduction 140 655-662. (doi:10.1530/REP-10-0288)

Park JY, Su YQ, Ariga M, Law E, Jin SL \& Conti M 2004 EGF-like growth factors as mediators of LH action in the ovulatory follicle. Science $\mathbf{3 0 3}$ 682-684. (doi:10.1126/science.1092463)

Prochazka R, Nagyova E, Rimkevicova Z, Nagay T, Kikuchi K \& Motlik J 1991 Lack of effect of oocytectomy on expansion of the porcine cumulus. Journal of Reproduction and Fertility 93 569-576. (doi:10.1530/jrf.0. 0930569)

Prochazka R, Srsen V, Nagyova E, Miyano T \& Flechon JE 2000 Developmental regulation of effect of epidermal growth factor on porcine oocyte-cumulus cell complexes: nuclear maturation, expansion, and F-actin remodeling. Molecular Reproduction and Development 56 63-73. (doi:10.1002/(SICI) 1098-2795(200005)56:1 <63::AID-MRD8>3.0.CO;2-D)

Prochazka R, Kalab P \& Nagyova E 2003 Epidermal growth factor-receptor tyrosine kinase activity regulates expansion of porcine oocyte-cumulus cell-complexes in vitro. Biology of Reproduction 68 797-803. (doi:10. 1095/biolreprod.102.005520)

Prochazka R, Petlach M, Nagyova E \& Nemcova L 2011 Effect of epidermal growth factor-like peptides on pig cumulus cell expansion, oocyte maturation, and acquisition of developmental competence in vitro: comparison with gonadotropins. Reproduction 141 425-435. (doi:10.1530/REP-10-0418)
Salustri A 2000 Paracrine actions of oocytes in the mouse pre-ovulatory follicle. International Journal of Developmental Biology 44 591-597.

Sela-Abramovich S, Chorev E, Galiani D \& Dekel N 2005 Mitogenactivated protein kinase mediates luteinizing hormone-induced breakdown of communication and oocyte maturation in rat ovarian follicles. Endocrinology 146 1236-1244. (doi:10.1210/en.2004-1006)

Shimada M, Idris Anas MK \& Terada T 1988 Phosphatidylinositol 3-kinase in cumulus cell sis responsible for meiotic progression from M I to M II stage in porcine follicular oocytes. Journal of Mammalian Ova Research 15 68-76. (doi:10.1274/jmor.15.68)

Shimada M, Maeda T \& Terada T 2001 Dynamic changes of connexin-43, gap junctional protein, in outer layers of cumulus cells are regulated by PKC and PI 3-kinase during meiotic resumption in porcine oocytes. Biology of Reproduction 64 1255-1263. (doi:10.1095/biolreprod64.4. 1255)

Shimada M, Ito J, Yamashita Y, Okazaki T \& Isobe N 2003 Phosphatidylinositol 3-kinase in cumulus cells is responsible for both suppression of spontaneous maturation and induction of gonadotropin-stimulated maturation of porcine oocytes. Journal of Endocrinology 179 25-34. (doi:10.1677/joe.0.1790025)

Shimada M, Hernandez-Gonzalez I, Gonzalez-Robayna I \& Richards JS 2006 Paracrine and autocrine regulation of epidermal growth factor-like factors in cumulus oocyte complexes and granulosa cells: key roles for prostaglandin synthase 2 and progesterone receptor. Molecular Endocrinology 20 1352-1365. (doi:10.1210/me.2005-0504)

Singh B \& Armstrong DT 1997 Insulin-like growth factor-1, a component of serum that enables porcine cumulus cells to expand in response to follicle-stimulating hormone in vitro. Biology of Reproduction $\mathbf{5 6}$ 1370-1375. (doi:10.1095/biolreprod56.6.1370)

Su YQ, Wigglesworth K, Pendola FL, O'Brien MJ \& Eppig JJ 2002 Mitogen-activated protein kinase activity in cumulus cells is essential for gonadotropin-induced oocyte meiotic resumption and cumulus expansion in the mouse. Endocrinology 143 2221-2232. (doi:10.1210/ en.143.6.2221)

Sun QY, Miao YL \& Schatten H 2009 Towards a new understanding on the regulation of mammalian oocyte meiosis resumption. Cell Cycle $\mathbf{8}$ 2741-2747. (doi:10.4161/cc.8.17.9471)

Vaccari S, Weeks JL II, Hsieh M, Menniti FS \& Conti M 2009 Cyclic GMP signaling is involved in the luteinizing hormone-dependent meiotic maturation of mouse oocytes. Biology of Reproduction 81 595-604. (doi:10.1095/biolreprod.109.077768)

Vanderhyden BC 1993 Species differences in the regulation of cumulus expansion by an oocyte-secreted factor(s). Journal of Reproduction and Fertility 98 219-227. (doi:10.1530/jrf.0.0980219)

Vanderhyden BC, Cohen JN \& Morley P 1993 Mouse oocyte regulate granulosa cell steroidogenesis. Endocrinology 133 423-426. (doi:10. 1210/en.133.1.423)

Villa-Diaz LG \& Miyano T 2004 Activation of p38 MAPK during porcine oocyte maturation. Biology of Reproduction 71 691-696. (doi:10.1095/ biolreprod.103.026310)

Wayne CM, Fan HY, Cheng X \& Richards JS 2007 Follicle-stimulating hormone induces multiple signaling cascades: evidence that activation of Rous sarcoma oncogene, RAS, and the epidermal growth factor receptor are critical for granulosa cell differentiation. Molecular Endocrinology 21 1940-1957. (doi:10.1210/me.2007-0020)

Yamashita Y, Hishinuma M \& Shimada M 2009 Activation of PKA, p38 MAPK and ERK $1 / 2$ by gonadotropins in cumulus cells is critical for induction of EGF-like factor and TACE/ADAM17 gene expression during in vitro maturation of porcine COCs. Journal of Ovarian Research 220. (doi:10.1186/1757-2215-2-20)

Received 25 May 2012

First decision 13 July 2012

Revised manuscript received 27 August 2012

Accepted 3 September 2012 